\title{
Quantitative Determination of Acetaldehyde in Foods Using Automated Digestion with Simulated Gastric Fluid Followed by Headspace Gas Chromatography
}

\author{
Michael Uebelacker and Dirk W. Lachenmeier \\ Chemisches und Veterinäruntersuchungsamt (CVUA) Karlsruhe, Weissenburger Straße 3, 76187 Karlsruhe, Germany \\ Correspondence should be addressed to Dirk W. Lachenmeier, lachenmeier@web.de
}

Received 8 January 2011; Accepted 31 March 2011

Academic Editor: Juan F. Garcia-Reyes

Copyright (c) 2011 M. Uebelacker and D. W. Lachenmeier. This is an open access article distributed under the Creative Commons Attribution License, which permits unrestricted use, distribution, and reproduction in any medium, provided the original work is properly cited.

\begin{abstract}
Acetaldehyde (ethanal) is a genotoxic carcinogen, which may occur naturally or as an added flavour in foods. We have developed an efficient method to analyze the compound in a wide variety of food matrices. The analysis is conducted using headspace (HS) gas chromatography (GC) with flame ionization detector. Using a robot autosampler, the samples are digested in full automation with simulated gastric fluid $\left(1 \mathrm{~h}\right.$ at $\left.37^{\circ} \mathrm{C}\right)$ under shaking, which frees acetaldehyde loosely bound to matrix compounds. Afterwards, an aliquot of the HS is injected into the GC system. Standard addition was applied for quantification to compensate for matrix effects. The precision of the method was sufficient ( $<3 \%$ coefficient of variation). The limit of detection was $0.01 \mathrm{mg} / \mathrm{L}$ and the limit of quantification was $0.04 \mathrm{mg} / \mathrm{L} .140$ authentic samples were analyzed. The acetaldehyde content in apples was $0.97 \pm 0.80 \mathrm{mg} / \mathrm{kg}$, orange juice contained $3.86 \pm 2.88 \mathrm{mg} / \mathrm{kg}$. The highest concentration was determined in a yoghurt $(17 \mathrm{mg} / \mathrm{kg})$. A first-exposure estimation resulted in a daily acetaldehyde intake of less than $0.1 \mathrm{mg} / \mathrm{kg}$ bodyweight from food, which is considerably lower than the exposures from alcohol consumption or tobacco smoking.
\end{abstract}

\section{Introduction}

Acetaldehyde (ethanal) is carcinogenic in animal experiments $[1,2]$ and was classified by the International Agency for Research on Cancer (IARC) in 1999 as "possibly carcinogenic to humans" (group 2B) [3]. Only recently, acetaldehyde in association with alcohol consumption has been upgraded by IARC into group 1 (i.e., the highest level of evidence) as "carcinogenic to humans" [4]. The carcinogenicity is considered to be caused by a genotoxic mechanism as several acetaldehyde-DNA adducts were found in vitro and in vivo [5-9]. For this reason, it is currently not possible to suggest a clear threshold or maximum tolerable limit for foods, but the margin of exposure model has to be used for risk assessment [10-13]. This requires to have robust occurrence data for exposure assessment.

In foods, acetaldehyde may occur either naturally or because of intentional addition as flavour compound [14]. Other sources of human exposure to acetaldehyde may be cosmetic products or environmental exposure from burning fossil fuels, but the major sources are tobacco smoke and exposure from ethanol oxidation following alcoholic beverage consumption $[11,13,15]$. In vivo, acetaldehyde may also be formed endogenously, but especially in the gastrointestinal tract by bacteria that metabolize ethanol or carbohydrates. In foods, the highest concentrations of acetaldehyde were determined in vinegar $(1.06 \mathrm{~g} / \mathrm{kg})$, but also in milk products and diverse fruits and vegetables $[16,17]$.

The Netherlands Organization for Applied Scientific Research (TNO) database "volatile compounds in foods (VCF)" lists numerous studies on the occurrence of acetaldehyde but most of these were from the 1980s or earlier [18]. An absence of current data about the occurrence of acetaldehyde in food can be noted, so that the aim of this study was to develop a methodology to most efficiently analyze acetaldehyde in a wide variety of food matrices, and also provide an overview on the occurrence in the most susceptible food groups. 
The most simplistic procedure for acetaldehyde analysis is the direct injection of a sample solution into a gas chromatograph with flame ionization detection (FID). Such a procedure can be used for analysis of alcoholic beverages without any further sample preparation and is also included in the EU reference methods for the analysis of spirits [19]. Our laboratory had participated in the interlaboratory trial, in which the EU procedure was evaluated for the first time [20], and has used it since then with success (as documented by regular participation in international interlaboratory trials), and our previous studies on acetaldehyde occurrence in alcoholic beverages were all based on this procedure [21-26]. As we are now interested to analyze other foods (besides alcoholic beverages), the reference procedure for spirits cannot be directly applied. The major problem is to obtain sample extracts without losses of the very volatile analyte that can be injected into the GC system. In the literature, several methods were suggested for acetaldehyde analysis in foods, which include photometric, fluorimetric, chromatographic, and enzymatic methods. However, some of the methods are either expensive or lack sensitivity (enzymatic method), include time-consuming sample preparation steps or lack in specificity (spectrophotometric methods) [27]. The extraction of acetaldehyde with steam distillation is generally judged as being problematic, as considerable losses may occur (up to $30 \%$ in unpublished studies by the authors). Furthermore, this procedure is leading to a dilution of the analyte, which may facilitate the need for an additional extraction step [28, 29]. Ott et al. [30] also stressed the fact that too strong warming during sample preparation must be prohibited, as this leads not only to volatilization but also increases the reactivity of acetaldehyde. A strong heating (e.g., in the headspace oven) may also lead to artefactual formation of acetaldehyde from ethanol, which may explain reports of very high concentrations in early studies [31].

Prior to chromatographic measurement of acetaldehyde, derivatization using 2,4-dinitrophenylhydrazine was suggested, and the formed hydrazone can be measured using gas chromatography (GC) or high-performance liquid chromatography (HPLC) [32]. Another derivatization reagent (cysteamine- $\mathrm{HCl}$ ) was suggested by Miyake and Shibamoto [33], which, however, needs careful adjustment of $\mathrm{pH}$ and a further extraction step. A simpler procedure is the analysis of underivatized acetaldehyde using headspace gas chromatography (HS-GC). The headspace injection can be used instead of the liquid injection while all other parameters of the EU reference method can be used. We have previously used such a HS-GC-FID procedure for the analysis of acetaldehyde in saliva samples $[13,34]$, and this work reports the modifications needed for analyzing all kinds of foodstuffs, including a validation of the procedure. Similar to our previous procedure, we use simple static HS injection, as it was previously shown that the dynamic variant ("purge and trap") is not possible as acetaldehyde is only insufficiently adsorbed into the usual materials (e.g., Tenax) [28]. This was confirmed by own experiments with headspace trap techniques [35].

We have set focus on providing a sample preparation without losses as well as an improved acid digestion that simulates physiological conditions of the human stomach and therefore allows to estimate the exposure after oral consumption of foods.

\section{Experimental}

2.1. Chemicals. Acetaldehyde ( $>99.5 \%$ ) was purchased from Fluka. Sodium chloride was from Riedel-de-Haen, and pepsin from porcine gastric mucosa $(800-2500 \mathrm{U} / \mathrm{mg}$ protein) was from Sigma-Aldrich. Hydrochloric acid (37\%) and ethanol (>99.9\%) were obtained from Merck. The simulated gastric fluid (SGF) was prepared according to USP 32 [36]. To compensate for the dilution, which occurs during sample preparation, the SGF was concentrated by a factor of 4 . For this, $4.0 \mathrm{~g}$ of sodium chloride were dissolved in $400 \mathrm{~mL}$ of distilled water and $4 \mathrm{~mL}$ of hydrochloric acid (37\%) were added, and finally $6.4 \mathrm{~g}$ of pepsin were added. After complete dissolution of the pepsin, the now slightly yellow coloured solution was filled up with distilled water to $500 \mathrm{~mL}$ [36]. To prepare an acetaldehyde stock solution with a concentration of $3.0 \mathrm{~g} / \mathrm{L}$, a $100 \mathrm{~mL}$ measuring flask is filled with about $80 \mathrm{~mL}$ of distilled water, which is temperated at exactly $20^{\circ} \mathrm{C}$, and $300 \mathrm{mg}$ of acetaldehyde are weighed into the flask. The flask is filled with distilled water to $100 \mathrm{~mL}$ and stored at 5$8^{\circ} \mathrm{C}$. The solution is stable for not more than 10 days. From this stock solution, the acetaldehyde standards were freshly prepared on each measuring day. The calibration curve was prepared by filling up 20,270, 520, and $720 \mu \mathrm{L}$ of the stock solution with distilled water in a $10 \mathrm{~mL}$ measuring flask (5.4$240 \mathrm{mg} / \mathrm{L}$ ). For spiking purposes, $800 \mu \mathrm{L}$ of stock solution were filled up with distilled water in a $50 \mathrm{~mL}$ measuring flask $(48 \mathrm{mg} / \mathrm{L})$. All standard and spiking solutions were stored in a water bath at $20^{\circ} \mathrm{C}$ till use. For basic calibration, $200 \mu \mathrm{L}$ of the standard solution, $1.25 \mathrm{~mL}$ of SGF and $3.55 \mathrm{~mL}$ of distilled water were given in a $20 \mathrm{~mL}$ headspace vial, which is immediately tightly sealed using a silicon/PTFE septum. The basic calibration was measured at least once weekly to check the performance of the GC system.

2.2. Sample Selection and Storage. The sample types were selected according to risk oriented principles [37] based on previously published acetaldehyde contents and the typical food intake in Germany. We excluded alcoholic beverages, as this group was previously analyzed in detail [22]. From the 140 products analyzed in total, we focused especially on dairy products $(n=43)$, fruits $(n=37)$, vegetables $(n=18)$, and alcohol-free beverages $(n=33)$. The samples were purchased in local retail sale. The samples were stored at $5-8^{\circ} \mathrm{C}$ and analyzed in fresh condition, or, for packaged foods, before the expiration of the "best before" date.

2.3. Sample Preparation. Liquid and semisolid foods were homogenized by shaking or stirring with a spoon. Dependent on consistency, the samples were weighed with help of a $20 \mathrm{~mL}$ disposable plastic syringe or using an Eppendorf pipette, with a tip that was cut off with scissors to facilitate the pipetting of semisolid samples. For quantification with standard addition, five aliquots (in the range of $1.2-2.0 \mathrm{~g}$ ) 
of the sample were weighed with an accuracy of $10 \mathrm{mg}$ into $20 \mathrm{~mL}$ headspace vials. After addition of $1.25 \mathrm{~mL}$ of SGF and the required acetaldehyde spiking, distilled water up to a total volume of $5 \mathrm{~mL}$ was added. The total time for sample preparation was $10-15$ min per sample.

Solid foods were homogenized in a standard household mixer (Magic Maxx, ds-produkte GmbH, Gallin). For fruits and vegetables only the edible parts were used (e.g., bananas and oranges were peeled prior to homogenization). The homogenized samples were weighed similar to the liquid foods described above. Only completely dry or highly viscous samples were weighed using a spatula. The total time for sample preparation of the solid foods was $15-25 \mathrm{~min}$ per sample. The prepared headspace vials were stored at $5-8^{\circ} \mathrm{C}$ and generally analyzed on the same day, but never later than on the next day after preparation.

2.4. Gas Chromatography. The HS-GC-FID system used for analysis was an Agilent model $6890 \mathrm{~N}$ gas chromatograph in combination with a CTC Combi PAL autosampler. To simulate the physiological conditions inside the stomach, the samples were incubated for $60 \mathrm{~min}$ at $37^{\circ} \mathrm{C}$ under constant stirring in the oven of the autosampler. After that, $500 \mu \mathrm{L}$ of headspace were injected into the GC system at $500 \mu \mathrm{L} / \mathrm{sec}$ with a temperature of the transfer syringe of $80^{\circ} \mathrm{C}$. Substances were separated on a capillary column (DB-WAX, $58 \mathrm{~m} \times 0.32 \mathrm{~mm}$ I.D., film thickness $0.50 \mu \mathrm{m})$. Temperature program: $30^{\circ} \mathrm{C}$ hold for $8 \mathrm{~min}, 14^{\circ} \mathrm{C} / \mathrm{min}$ up to $200^{\circ} \mathrm{C}$, hold for $10 \mathrm{~min}$. The temperatures for the injection port and FID were set at $140^{\circ} \mathrm{C}$ and $210^{\circ} \mathrm{C}$, respectively. Splitless injection mode and helium with a flow rate of $2.0 \mathrm{~mL} / \mathrm{min}$ as carrier gas was used. Data acquisition and peak integration were performed using Chromeleon 6.8 Chromatography Data System (Dionex Corporation, Sunnyvale, USA). The data analysis of the standard additions to calculate the concentrations was conducted using Valoo 2.3 (Analytik Software, Leer, Germany). The standard additions were only evaluated in the case of a correlation coefficient with a minimum of 0.9995 and a coefficient of variation (CV) of not more than 3\%. Per calibration one outlier was tolerated and eliminated. If the criteria were not fulfilled after elimination of this one outlier, the results were discarded and the sample preparation and measurement were repeated from the beginning.

2.5. Validation Studies. The limits of detection and quantification were determined according to German norm 32645 [38] using the calibration curve method. The limits are extrapolated based on the tolerance interval of a calibration curve, which is measured with concentrations surrounding the limits. This method gives more realistic limits than extrapolation from blank measurements (signal/noise ratios). The calibration curve was established in the range between $0.063-0.631 \mathrm{mg} / \mathrm{L}$ with equidistant calibrators $(n=$ 10).

The precision (expressed as coefficient as variation) can be directly calculated for each sample from the calibration curve resulting from standard addition (5 aliquots measured per sample). Furthermore, we have measured one yoghurt sample several times with different amounts of sample weight $(1.2,1.4$, and $1.6 \mathrm{~g})$. The storage stability was evaluated by preparing three standard addition series of the same yoghurt sample and measuring them after 2, 9, and 16 days after preparation (the prepared headspace vials were stored at $5-8^{\circ} \mathrm{C}$ in the meantime).

To test for artefactual formation of acetaldehyde from ethanol during sample preparation or analysis, two standard addition series of an apple sample were prepared with and without addition of ethanol ( $250 \mu \mathrm{g}$ ethanol per sample vial).

Possible losses during sample preparation were tested as follows: (1) $50 \mathrm{~mL}$ of an acetaldehyde stock solution in a $100 \mathrm{~mL}$ measuring flask was left to stand open (i.e., without stopper on the flask) for $65 \mathrm{~min}$ in the $20^{\circ} \mathrm{C}$ water bath (normally, the flask are directly sealed after the pipetting of the standard, of course). (2) $100 \mathrm{~mL}$ of standard solution were filled into the mixer used for homogenization and mixed for $20 \mathrm{~s}$ similar to the samples.

2.6. Light Microscopy of Buttermilk. During initial method development, it was noted that buttermilk did not contain any detectable acetaldehyde in the headspace if aqueous samples are analyzed. After addition of SGF, considerable amounts of acetaldehyde were found, however. To research the influence of SGF on the matrix, light microscopy was conducted (Axiostar plus, camera: AxioCam ICC1, Carl Zeiss GmbH, Oberkochen). Acetaldehyde was coloured using Schiff reagent (Merck).

\section{Results and Discussion}

3.1. Matrix Effect on Headspace Recovery of Acetaldehyde. Preliminary experiments had shown that the differences in matrix composition have massive influences on the recovery of acetaldehyde in the headspace. For this reason, external calibration with aqueous standards is not possible. Due to the diversity of matrices we wanted to analyze, it would also not have been possible to conduct calibration in matrix, with the additional problem of finding acetaldehyde-free matrices for spiking. It was also not possible to find a suitable internal standard with similar behaviour to acetaldehyde, and the use of mass spectrometry with the possibility to use isotopically labelled acetaldehyde was not possible for instrumental restrictions and cost reasons. For all these reasons, we decided to use standard addition according to the German norm 32633:1998 [39]. For this we used 5 aliquots of each sample, from which one was measured without spiking and four were spiked with increasing amounts of acetaldehyde in equidistant concentrations (generally we spiked $0,4,8,12$, and $16 \mu \mathrm{g}$ per $\mathrm{g}$ of sample weight). All sample aliquots were filled up to the same volume $(5 \mathrm{~mL})$ with water. The selection of 5 aliquots results from a compromise between precision and work efforts, because a smaller number of aliquots would considerably increase the measurement error. While the standard addition sounds to be an incredible amount of work, we nevertheless judged it to be superior to all other methods. First, it must be noted that 


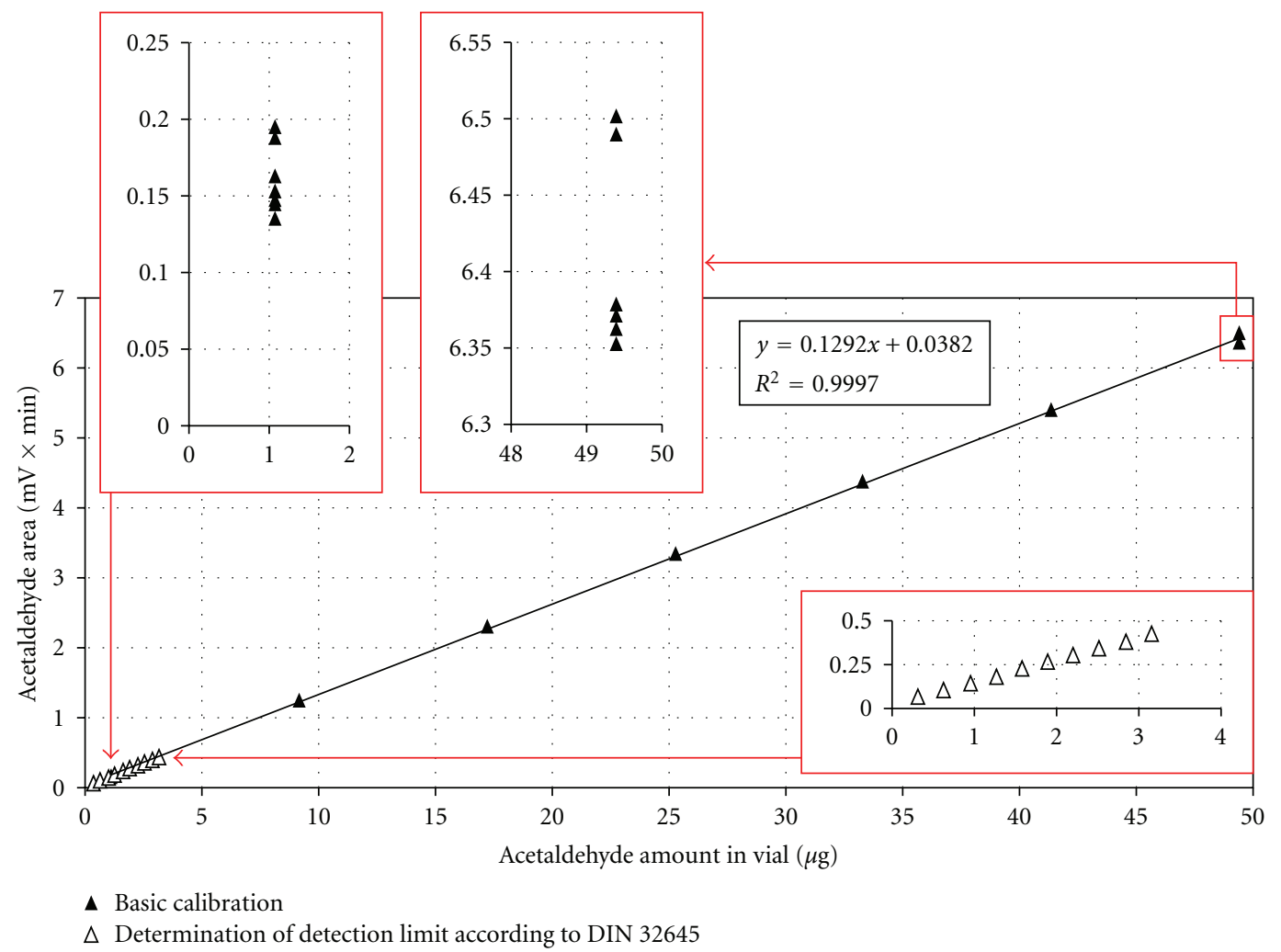

FIgURE 1: Regression curve of the basic calibration including the determination of the detection limit in the lower range.

all steps besides the weighing of the samples are conducted automatically on the autosampler. An extraction using solidphase extraction or liquid-liquid extraction would have been a similarly large effort for the preparation, with additional problems of loss of the analyte. A further search for an internal standard with same volatility, solubility, reactivity, and headspace behaviour as acetaldehyde was also judged to be pointless, especially as free retention time windows in the complex food matrices are very restricted.

3.2. Method Validation. The basic calibration using external standards showed an acceptable linearity and precision in the working range $\left(R^{2}=0.9997, \mathrm{CV} 1.47 \%\right)$. The homogeneity of variances shows that the method is equally precise for the whole working range (Figure 1). The limit of detection was $0.01 \mathrm{mg} / \mathrm{L}$ and the limit of quantification was $0.04 \mathrm{mg} / \mathrm{L}$, which is in the same order of magnitude as the limits determined in previous research $[28,40,41]$.

Examples of calibration in different matrices are shown in Figure 2. The matrix effect leads to a drastic influence on the slopes of the calibration lines, which necessitates the use of standard addition for quantification. It must be noted that the matrix effect depends on the sample weight, and can be reduced by decreasing the weight. However, this may pose the problem that the response falls below the quantification limit. On the other hand, the sample amount should not be selected too high, because the increase may even result in reduced response, as demonstrated for an apple sample shown in Figure 3. In yoghurt and banana samples, which were analyzed in the same fashion as the apple sample, this effect was not observed, however.

With the exception of a single sample of roast coffee powder $\left(R^{2}=0.9987, \mathrm{CV} 3.28 \%\right)$, all samples fulfilled our requirements for precision $\left(R^{2}>0.9990, \mathrm{CV}<3 \%\right)$. Apart from 8 samples (peas, roast coffee, apple soft drink, orange soft drink, paprika, and 3 bananas), we even had $R^{2}$ of $>0.9995$ and the CVs were typically below $2 \%$. The yoghurt sample that was independently measured for 3 times, had a CV of $2.59 \%$ (average $6.18 \mathrm{mg} / \mathrm{kg}$, standard deviation $0.16 \mathrm{mg} / \mathrm{kg}$ ). Only one sample (a radish) was not measurable at all, because there was a large interference near the retention time of acetaldehyde, which overlapped its peak and hindered correct integration, probably derived from a glucosinolate or glucosinolate degradation product. MS detection would be required in such cases.

During the storage stability experiment, no significant difference in the results was seen between the yoghurt samples stored for 2, 9, or 16 days. The overall mean was $16.91 \mathrm{mg} / \mathrm{kg}$ (standard deviation $0.49 \mathrm{mg} / \mathrm{kg}$, CV $2.90 \%$ ). No artefactual formation of acetaldehyde was detected in the apple sample series with spiked ethanol $(2.39 \pm 0.47 \mathrm{mg} / \mathrm{kg}$ without ethanol; $2.35 \pm 0.32 \mathrm{mg} / \mathrm{kg}$ with ethanol).

Regarding the losses during sample preparation, the highest influence had the storage of the stock solution without stopper ( $4 \%$ loss of acetaldehyde during $65 \mathrm{~min}$ ), while during homogenization only a minor loss of $2 \%$ occurred. The samples were stored in a fridge and the temperature in the samples during mixing was increased by a maximum 


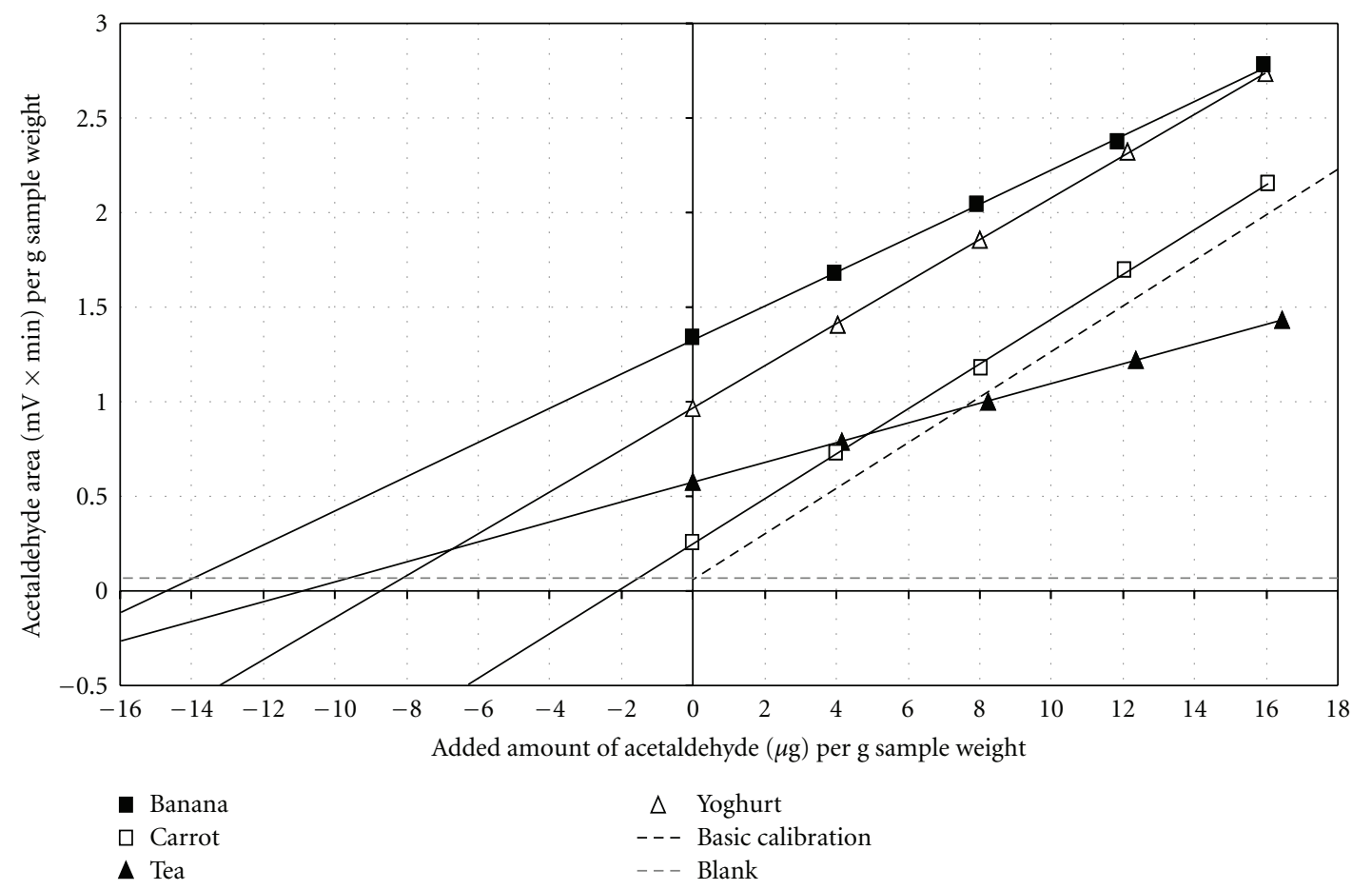

FIGURE 2: Standard addition curves of four selected samples compared to basic calibration.

of $7^{\circ} \mathrm{C}$ (in the case of a cheddar cheese). We assume that no massive losses of acetaldehyde occur (boiling point $20.1-20.8^{\circ} \mathrm{C}$ ). The loss during sample preparation of solid matrices in the mixer is therefore deemed as acceptable, but unavoidable.

Our validation results show that the method has an acceptable performance for the use of analyzing food matrices. Due to the volatility of acetaldehyde, careful handling of the stock solutions is required to avoid losses.

3.3. The Special Case of Buttermilk. The regression curves for different spiking levels of acetaldehyde in buttermilk are shown in Figure 4. Without the use of SGF, no acetaldehyde at all was recovered at the standard spiking levels. Using less sample amount and higher spiking levels, acetaldehyde can be detected. Apparently, the matrix needs to be saturated till the excess of acetaldehyde can diffuse into the headspace. Interestingly, this phenomenon was only noted for buttermilk, but not for other matrices, for example, yoghurt. The microscopic results of buttermilk are shown in Figure 5. Macroscopically, both solutions (with and without SGF) had the same colour after colouring with Schiff reagent. Microscopically, the buttermilk without SGF shows large particulate agglomerations, in which the colour is concentrated. If the sample is treated with SGF, the agglomerations disappear and the colour becomes evenly distributed. According to the literature, milk fat globule membranes, which are broken down during buttermilk making, can interact with casein-micelles and form globular aggregates [42, 43]. In neutral aqueous solution, these aggregates are stabile and obviously bind acetaldehyde very effectively. In other milk products (i.e., yoghurt), where the milk fat globule membranes are occurring in intact form, acetaldehydebinding aggregates are apparently not yet formed. As the SGF preparation adequately frees the acetaldehyde, we have refrained from performing further experiments, while from a scientific standpoint it would be interesting to further study the binding behaviour of acetaldehyde in buttermilk, for example using transmission electron microscopy.

3.4. Survey of Authentic Samples. The results from 140 samples are presented in Table 1. A typical chromatogram is shown in Figure 6. The maximum content of foods for direct consumption was found in a yoghurt $(17.42 \mathrm{mg} / \mathrm{kg})$. In food ingredients, $26.3 \mathrm{mg} / \mathrm{kg}$ were found in a baking flavour, while an industrial orange flavour contained $1416 \mathrm{mg} / \mathrm{kg}$ of acetaldehyde, which was the maximum of all analysed samples.

In milk products, a correlation between acetaldehyde and fat content was not detectable. Goat milk products had lower acetaldehyde contents than cow milk products. This can be explained by its higher glycin concentration, which acts as inhibitor of threonine-aldolase, which may produce acetaldehyde from threonine [44].

In fruits, the highest acetaldehyde contents were found in bananas and in citrus fruits. Some apple varieties (Granny Smith, Elstar) showed higher contents than the other varieties, but the number of samples analyzed does not allow any conclusions on influence of variety. There could also be an influence of other factors not controlled, for example, environment during storage, climate, country of origin, and so forth. It would be interesting, however, to further investigate if certain varieties of apples are especially 


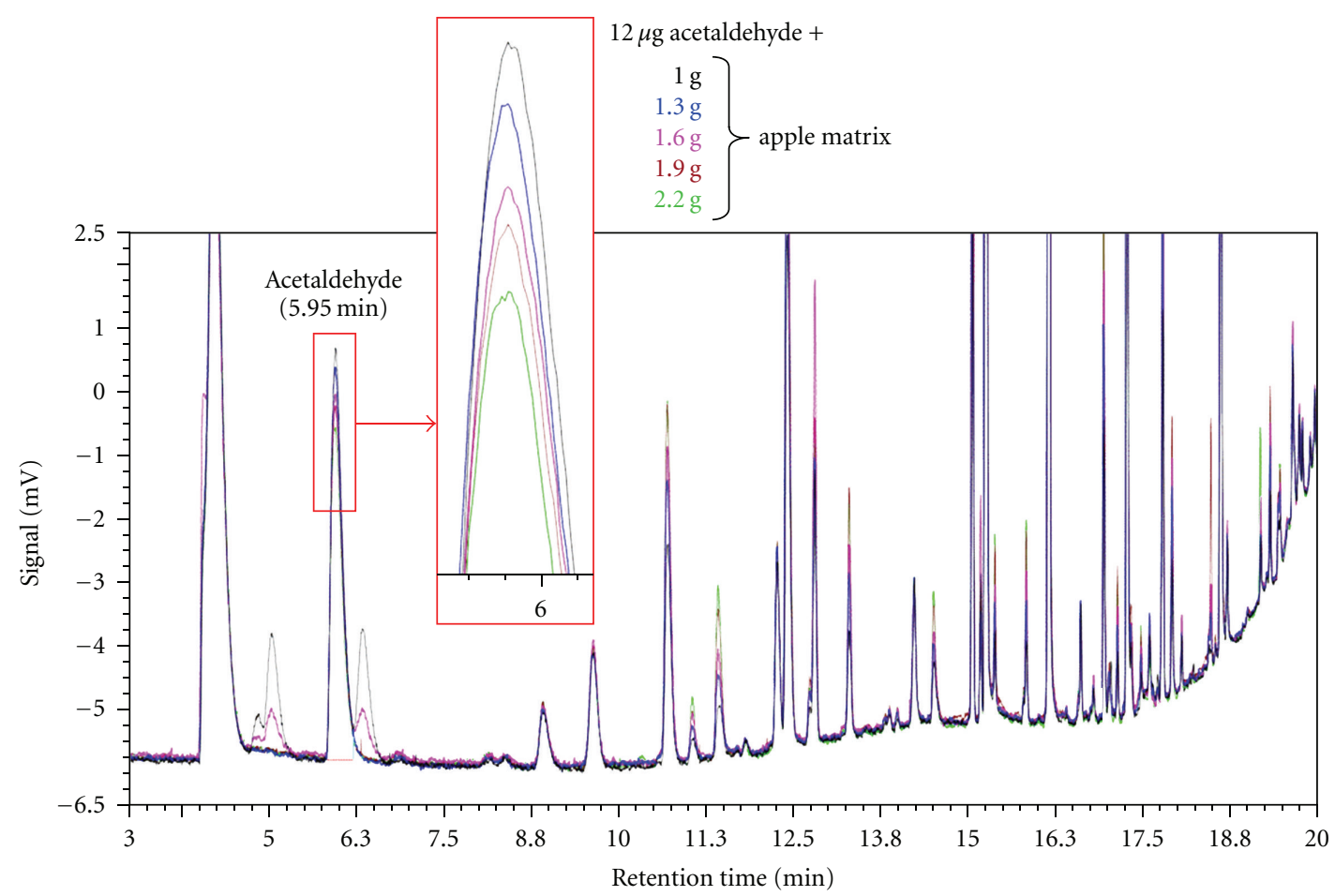

FIGURE 3: Reduced response due to matrix increase demonstrated by a spiked apple sample.

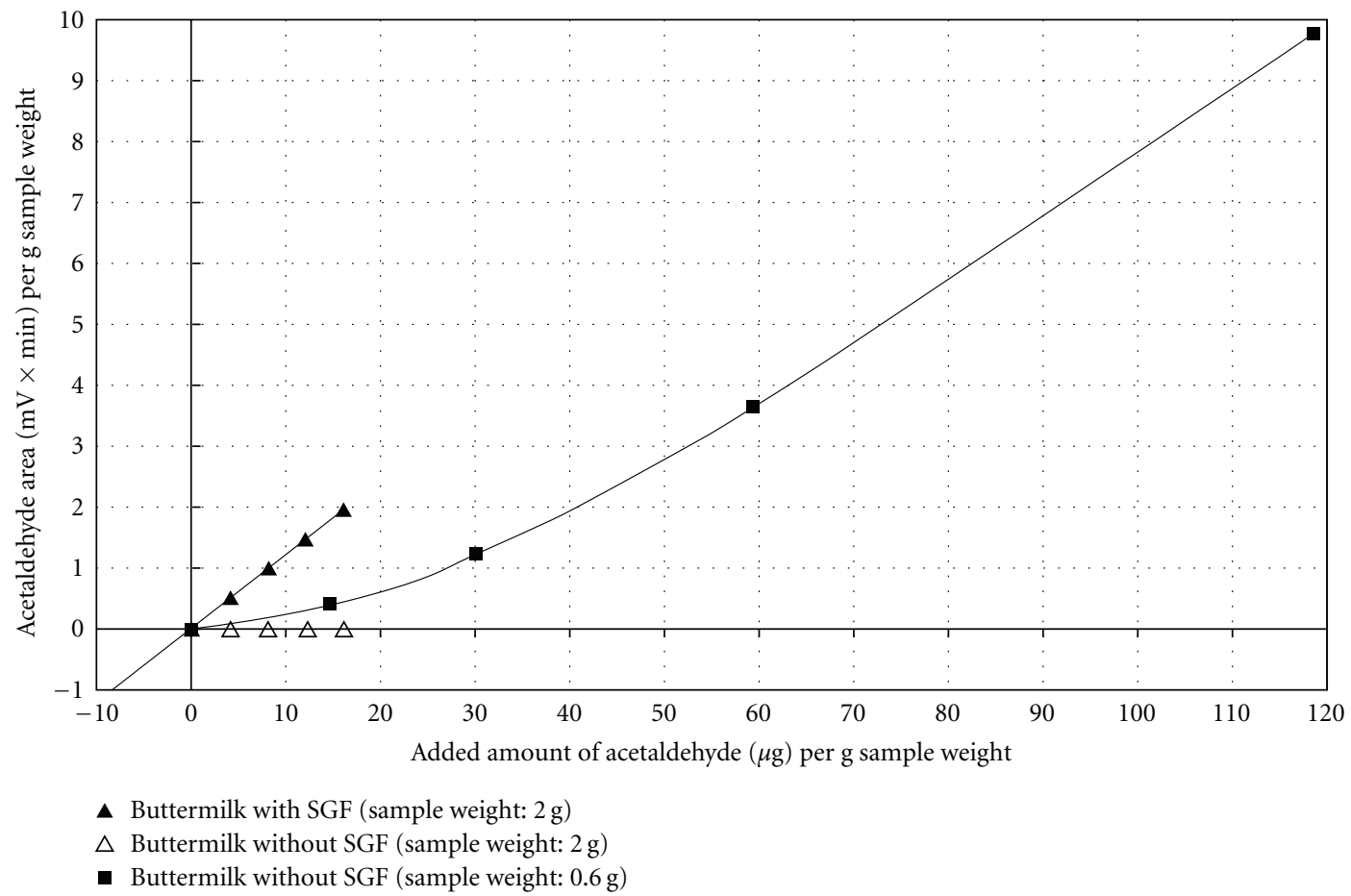

FIgURE 4: Standard addition curves of a buttermilk sample measured with and without simulated gastric fluid (SGF).

susceptible for acetaldehyde content. While all fruits were generally analyzed in fresh state, we made an experiment with bananas and followed the acetaldehyde content during ripening (Figure 7). The bananas for this experiment came from the same hand and were stored in a fridge up to 22 days. Similar to the blackening of the colour, the acetaldehyde content rose up to an increase of $80 \%$ compared to the initial content.

The fruit juices had in general less acetaldehyde than the corresponding fresh fruits. Causative could be on the one 
TABLE 1: Results of acetaldehyde analyses in selected foods.

\begin{tabular}{|c|c|c|}
\hline Food & Acetaldehyde content (mg/kg) & $\mathrm{CV}(\%)$ \\
\hline \multicolumn{3}{|l|}{ Milk products } \\
\hline $\begin{array}{l}\text { Ayran A } \\
\text { (Turkish milk product) }\end{array}$ & 5.79 & 1.35 \\
\hline $\begin{array}{l}\text { Ayran B } \\
\text { (Turkish milk product) }\end{array}$ & 6.51 & 1.42 \\
\hline $\begin{array}{l}\text { Ayran C } \\
\text { (Turkish milk product) }\end{array}$ & 9.79 & 1.78 \\
\hline Buttermilk & 0.01 & 0.52 \\
\hline Crème fraiche & 1.78 & 1.21 \\
\hline $\begin{array}{l}\text { Yoghurt with fruits } \\
\text { (banana, granadilla, } \\
\text { low-fat yoghurt) }\end{array}$ & 4.40 & 1.25 \\
\hline $\begin{array}{l}\text { Yoghurt with fruits } \\
\text { (apple, vanilla, low-fat } \\
\text { yoghurt) }\end{array}$ & 3.35 & 0.54 \\
\hline $\begin{array}{l}\text { Fruit-yoghurt } \\
\text { (strawberry) }\end{array}$ & 2.77 & 1.03 \\
\hline $\begin{array}{l}\text { Fruit-yoghurt } \\
\text { (Raspberries, } \\
\text { red-currant, low-fat } \\
\text { yogurt) }\end{array}$ & 5.62 & 1.57 \\
\hline $\begin{array}{l}\text { Yoghurt A } 1 \\
\text { (low-fat yoghurt) }\end{array}$ & 17.42 & 0.24 \\
\hline $\begin{array}{l}\text { Yoghurt A } 2 \\
\text { (low-fat yoghurt) }\end{array}$ & 16.44 & 2.34 \\
\hline $\begin{array}{l}\text { Yoghurt A } 3 \\
\text { (low-fat yoghurt) }\end{array}$ & 16.89 & 1.46 \\
\hline Yoghurt B 1 & 6.05 & 1.61 \\
\hline Yoghurt B 2 & 6.15 & 1.81 \\
\hline Yoghurt B 3 & 6.36 & 1.42 \\
\hline Yoghurt C & 8.38 & 0.73 \\
\hline Yoghurt D & 12.35 & 0.10 \\
\hline Yoghurt E & 9.66 & 0.28 \\
\hline Yoghurt F 1 & 13.77 & 0.53 \\
\hline Yoghurt F 2 & 12.75 & 1.26 \\
\hline $\begin{array}{l}\text { Yoghurt mild A } \\
\text { (low-fat yoghurt) }\end{array}$ & 12.61 & 1.25 \\
\hline Yoghurt mild A & 8.48 & 1.55 \\
\hline $\begin{array}{l}\text { Yoghurt mild B } \\
\text { (low-fat yoghurt) }\end{array}$ & 7.27 & 1.07 \\
\hline $\begin{array}{l}\text { Yoghurt mild D } \\
\text { (low-fat yoghurt) }\end{array}$ & 9.43 & 1.32 \\
\hline Yoghurt mild A & 13.61 & 1.40 \\
\hline $\begin{array}{l}\text { Yoghurt mild F } \\
\text { (goat milk) }\end{array}$ & 2.40 & 0.76 \\
\hline $\begin{array}{l}\text { Yoghurt mild G } \\
\text { (sheep milk) }\end{array}$ & 11.54 & 0.76 \\
\hline $\begin{array}{l}\text { Yoghurt mild H } \\
\text { (sheep milk) }\end{array}$ & 11.07 & 0.19 \\
\hline Kefir mild A & 1.48 & 0.29 \\
\hline Kefir mild B & 0.01 & 0.18 \\
\hline Sour milk A & 1.19 & 1.52 \\
\hline
\end{tabular}

Table 1: Continued.

\begin{tabular}{|c|c|c|}
\hline Food & Acetaldehyde content (mg/kg) & $\mathrm{CV}(\%)$ \\
\hline Sour milk & 0.19 & 0.14 \\
\hline Sour cream A & 0.47 & 0.31 \\
\hline Sour cream B & 4.26 & 0.30 \\
\hline Sour cream C & 6.28 & 1.43 \\
\hline Cheddar cheese & 0.22 & 0.82 \\
\hline Fresh cheese A & 0.68 & 0.39 \\
\hline Fresh cheese B & 1.06 & 0.90 \\
\hline Gouda cheese & 0.16 & 0.22 \\
\hline $\begin{array}{l}\text { Quark, fresh cheese } \\
\text { (low fat) }\end{array}$ & 1.81 & 0.07 \\
\hline $\begin{array}{l}\text { Quark, fresh cheese } \\
(20 \%)\end{array}$ & 1.07 & 0.91 \\
\hline $\begin{array}{l}\text { Quark C, fresh cheese } \\
\text { (low fat) }\end{array}$ & 0.12 & 0.94 \\
\hline $\begin{array}{l}\text { Quark D, fresh cheese } \\
\text { (low fat) }\end{array}$ & 2.05 & 1.70 \\
\hline \multicolumn{3}{|l|}{ Fruits } \\
\hline Pineapple & 0.63 & 1.09 \\
\hline Apple A (Elstar) & 1.81 & 0.73 \\
\hline Apple B (Pink Lady) & 0.32 & 0.06 \\
\hline Apple C (Jonagold) & 0.57 & 0.26 \\
\hline Apple D (Boskoop) & 0.40 & 0.29 \\
\hline Apple E (Tenroy Gala) & 0.52 & 0.89 \\
\hline $\begin{array}{l}\text { Apple F.1 } \\
\text { (Golden Delicious) }\end{array}$ & 2.39 & 1.06 \\
\hline $\begin{array}{l}\text { Apple F.2 } \\
\text { (Golden Delicious) }\end{array}$ & 2.35 & 1.01 \\
\hline Apple G (Granny Smith) & 0.76 & 1.77 \\
\hline Apricots & 1.57 & 1.07 \\
\hline Banana A.1 & 10.13 & 1.91 \\
\hline Banana A.2 & 16.36 & 2.36 \\
\hline Banana A.3 & 14.39 & 1.95 \\
\hline Banana A.4 & 18.27 & 2.33 \\
\hline Banana B & 2.21 & 1.13 \\
\hline Banana C & 14.78 & 2.33 \\
\hline Banana D & 1.88 & 0.43 \\
\hline Banana E & 7.52 & 1.07 \\
\hline Pear & 3.74 & 0.74 \\
\hline Strawberry & 1.29 & 1.57 \\
\hline Grapefruit & 3.23 & 0.30 \\
\hline Bilberries & 2.11 & 0.85 \\
\hline Kiwi fruit A & 0.73 & 1.30 \\
\hline Kiwi fruit B & 0.81 & 0.75 \\
\hline Mandarin & 0.78 & 0.95 \\
\hline Mango & 1.19 & 0.76 \\
\hline Orange A & 5.56 & 0.12 \\
\hline Orange B & 8.37 & 0.22 \\
\hline Papaya & 0.83 & 0.83 \\
\hline
\end{tabular}


TABle 1: Continued.

\begin{tabular}{|c|c|c|}
\hline Food & Acetaldehyde content (mg/kg) & $\mathrm{CV}(\%)$ \\
\hline Grapes (red) & 0.91 & 1.78 \\
\hline Lemon & 3.92 & 1.93 \\
\hline Apple puree & 0.41 & 1.91 \\
\hline $\begin{array}{l}\text { Fruit preparation with } \\
\text { apples and bananas }\end{array}$ & 0.37 & 1.16 \\
\hline $\begin{array}{l}\text { Fruit preparation with } \\
\text { bananas and yoghurt }\end{array}$ & 1.41 & 0.32 \\
\hline $\begin{array}{l}\text { Fruit preparation with } \\
\text { pears }\end{array}$ & 1.17 & 0.31 \\
\hline Mandarins (canned) & 3.13 & 0.02 \\
\hline Banana chips (roasted) & 0.98 & 1.11 \\
\hline \multicolumn{3}{|l|}{ Vegetables } \\
\hline Cucumber & 1.56 & 0.46 \\
\hline Carrot & 1.91 & 1.81 \\
\hline Garlic & 5.60 & 1.22 \\
\hline Cabbage turnip & 2.88 & 1.10 \\
\hline Capsicum (yellow) & 0.17 & 2.48 \\
\hline Capsicum (red) & 0.10 & 1.19 \\
\hline Beetroot & 0.15 & 0.47 \\
\hline Tomato & 0.05 & 1.81 \\
\hline Onion & 1.06 & 0.03 \\
\hline Pickled gherkin & 2.61 & 1.25 \\
\hline Sweet corn (canned) & 1.29 & 0.45 \\
\hline Sauerkraut (canned) & 2.37 & 1.42 \\
\hline Asparagus (canned) & 0.40 & 1.74 \\
\hline Carrots (canned) & 1.60 & 1.17 \\
\hline Peas (canned) & 4.49 & 2.61 \\
\hline Fresh beans (canned) A & 1.01 & 0.75 \\
\hline Fresh beans (canned) B & 1.01 & 1.50 \\
\hline Lentils (canned) & 0.10 & 0.57 \\
\hline \multicolumn{3}{|l|}{ Other foods } \\
\hline Strawberry jam & 0.26 & 0.31 \\
\hline Plum puree & 0.97 & 1.84 \\
\hline Honey & 1.01 & 0.60 \\
\hline Wheat and rye bread & 1.50 & 1.63 \\
\hline $\begin{array}{l}\text { Rye whole-meal bread } \\
\text { with pumpkinseed }\end{array}$ & 2.68 & 0.62 \\
\hline Vinegar & 2.61 & 1.35 \\
\hline Mustard & 0.15 & 0.65 \\
\hline $\begin{array}{l}\text { Lemon flavour for } \\
\text { baking }\end{array}$ & 26.32 & 1.27 \\
\hline Orange flavour & 1416 & 0.83 \\
\hline \multicolumn{3}{|l|}{ Alcohol-free beverages } \\
\hline $\begin{array}{l}\text { Pineapple juice } \\
\text { (direct juice) }\end{array}$ & 0.01 & 0.85 \\
\hline Apple juice (direct juice) & 5.72 & 0.60 \\
\hline Banana nectar A & 0.26 & 0.95 \\
\hline Banana nectar B & 0.45 & 1.25 \\
\hline
\end{tabular}

Table 1: Continued.

\begin{tabular}{|c|c|c|}
\hline Food & Acetaldehyde content (mg/kg) & CV $(\%)$ \\
\hline Peach nectar & 0.52 & 1.51 \\
\hline $\begin{array}{l}\text { Orange juice } \\
\text { (from concentrate) }\end{array}$ & 1.83 & 0.92 \\
\hline $\begin{array}{l}\text { Orange juice } \\
\text { (direct juice) }\end{array}$ & 5.89 & 0.94 \\
\hline $\begin{array}{l}\text { Smoothie strawberry } \\
\text { banana }\end{array}$ & 3.06 & 1.58 \\
\hline Grape juice (direct juice) & 0.97 & 1.85 \\
\hline Ice tea (peach flavour) & 4.32 & 1.05 \\
\hline Energy drink A & 1.08 & 1.43 \\
\hline Energy drink B & 0.06 & 0.82 \\
\hline Energy drink C & 0.36 & 0.27 \\
\hline $\begin{array}{l}\text { Soft drink (with } \\
\text { fermented cranberry) }\end{array}$ & 3.49 & 0.92 \\
\hline $\begin{array}{l}\text { Soft drink (with } \\
\text { fermented quince) }\end{array}$ & 0.32 & 0.75 \\
\hline $\begin{array}{l}\text { Soft drink (with } \\
\text { fermented herbs) }\end{array}$ & 0.33 & 1.16 \\
\hline Cola & 0.28 & 0.66 \\
\hline Apple soft drink & 7.54 & 1.07 \\
\hline Cherry soft drink & 0.93 & 1.68 \\
\hline Orange soft drink A & 16.30 & 2.28 \\
\hline Orange soft drink B & 14.01 & 0.25 \\
\hline Wild beery soft drink & 2.39 & 2.18 \\
\hline Carrot juice (fermented) & 1.14 & 0.67 \\
\hline $\begin{array}{l}\text { Carrot juice } \\
\text { (direct juice) }\end{array}$ & 2.49 & 0.82 \\
\hline $\begin{array}{l}\text { Tomato juice } \\
\text { (from concentrate) }\end{array}$ & 0.15 & 1.37 \\
\hline $\begin{array}{l}\text { Instant coffee A } \\
\text { (powder) }\end{array}$ & 35.51 & 0.44 \\
\hline $\begin{array}{l}\text { Instant coffee A } \\
(2 \mathrm{~g} \text { per } 180 \mathrm{~mL})\end{array}$ & 0.26 & 0.35 \\
\hline $\begin{array}{l}\text { Instant coffee B } \\
\text { (powder) }\end{array}$ & 31.20 & 1.70 \\
\hline $\begin{array}{l}\text { Coffee, roasted A } \\
\text { (powder) }\end{array}$ & 40.14 & 3.28 \\
\hline $\begin{array}{l}\text { Coffee, roasted A } \\
\text { (powder) }\end{array}$ & 1.15 & 1.19 \\
\hline $\begin{array}{l}\text { Coffee, roasted B } \\
\text { (powder) }\end{array}$ & 36.26 & 2.49 \\
\hline Earl Grey tea (leaves) & 9.84 & 0.99 \\
\hline Green tea (leaves) & 1.35 & 0.34 \\
\hline
\end{tabular}

hand losses of the volatile compound during pressing or concentration of the juice, as well as a dilution effect in products with less than 100\% fruit content. The content in direct juices was for the same reason higher than in juices from concentrate. This is consistent with previous observations [45]. 
TABLE 2: Estimation of total acetaldehyde exposure (in $\mu \mathrm{g} / \mathrm{kg}$ bodyweight/day) from food consumption (excluding alcoholic beverages) using a combination of different scenarios for the acetaldehyde levels in foods and the consumed amounts.

\begin{tabular}{|c|c|c|c|c|c|c|c|c|}
\hline \multirow{2}{*}{$\begin{array}{l}\text { Acetaldehyde } \\
\text { content in the food }\end{array}$} & \multicolumn{4}{|c|}{ Consumption (men) } & \multicolumn{4}{|c|}{ Consumption (women) } \\
\hline & Average & Fifth percentile & Median & 95th percentile & Average & Fifth percentile & Median & 95th percentile \\
\hline Average & 42 & 1 & 20 & 161 & 44 & 2 & 27 & 147 \\
\hline Fifth percentile & 6 & 1 & 4 & 17 & 6 & 1 & 5 & 16 \\
\hline 25th percentile & 12 & 1 & 8 & 38 & 14 & 1 & 10 & 39 \\
\hline Median & 24 & 1 & 14 & 83 & 28 & 2 & 19 & 86 \\
\hline 90th percentile & 105 & 1 & 44 & 431 & 106 & 4 & 61 & 372 \\
\hline 95th percentile & 119 & 1 & 49 & 487 & 120 & 5 & 70 & 418 \\
\hline 99th percentile & 137 & 2 & 60 & 547 & 142 & 6 & 87 & 483 \\
\hline
\end{tabular}

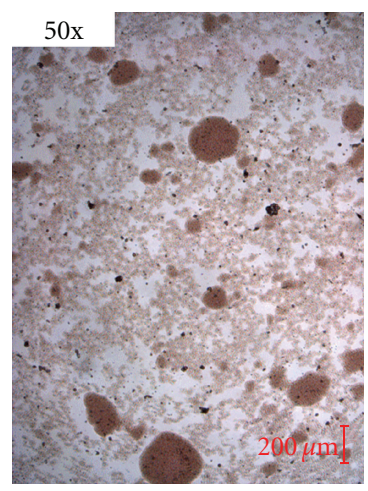

Buttermilk + Schiff reagent

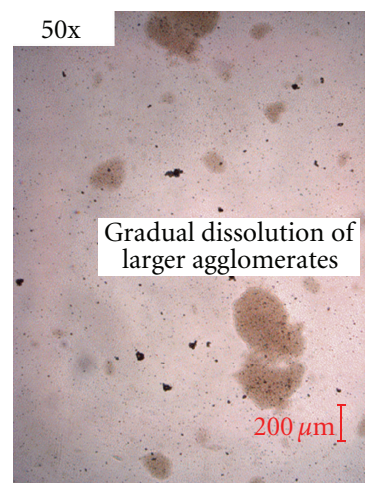

Buttermilk + Schiff reagent + stimulated gastric fluid
FIGURE 5: Microscopic analysis of buttermilk samples after colouration with Schiff reagent.

Strikingly high acetaldehyde contents were detected in lemonades or soft drinks that only contain low amounts of fruit juice (apple drink $7.5 \mathrm{mg} / \mathrm{kg}$, orange soft drink $15 \mathrm{mg} / \mathrm{kg}$ ). In view of the results found naturally in the fruits, these contents can only be explained if acetaldehyde has been added as flavour compound, which is consistent with the labelling of the products ("flavour" was given in the ingredients list).

Compared to the literature, our survey results were generally consistent compared to the previous data. The exception are the results of Lund et al. [46] for orange juice, which contained 50-130 mg/L while grapefruit juice contained 40$230 \mathrm{mg} / \mathrm{L}$. The plausibility of these values is questionable as other authors never reported acetaldehyde contents this high in these fruit juices again $[45,47,48]$. Another inconsistency in the literature is the reporting of a maximum acetaldehyde content of $400 \mathrm{mg} / \mathrm{kg}$ in peas in the VCF database [18]. This is clearly an input data error, as the original reference [49] reported $400 \mathrm{mg} / \mathrm{kg}$ not for acetaldehyde but for ethanol. If this value is deleted, the range for acetaldehyde in peas would be $0.56-2.4 \mathrm{mg} / \mathrm{kg}$. Very high values were also reported for vinegar $(1.9-1060 \mathrm{mg} / \mathrm{kg})$ [18]. This can be traced back to the publication of Jones and Greenshield [50], who reported a range of $20-1060 \mathrm{mg} / \mathrm{kg}$ for malt vinegar. In our opinion, conventional table vinegar contains significantly less acetaldehyde. Finally, the VCF database [18] reported higher values for yoghurt, than what was found in our study $(0.7-76 \mathrm{mg} / \mathrm{kg})$. However, it must be pointed out that all references reporting contents above $20 \mathrm{mg} / \mathrm{kg}$ were from 1982 and earlier, so that these probably resulted from analytical deficiencies (artefactual formation) or represent technological changes.

3.5. Exposure Estimation. The Joint FAO/WHO Expert Committee on Food Additives (JECFA) [51] has estimated the acetaldehyde amount, which is ingested due to its use as food flavour additive, in the range of 9.7-11 $\mathrm{mg}$ per person per day. The Food Safety Commission of Japan [52] has estimated a similar range between $9.618 \mathrm{mg}$ (Europe) and $19.211 \mathrm{mg}$ (USA), which was assumed to be $20 \%$ of the acetaldehyde that is contained in foods while the other $80 \%$ can be traced as natural occurrence. From these data a total acetaldehyde exposure of $48-96 \mathrm{mg} /$ day $(0.64-1.28 \mathrm{mg} / \mathrm{kg}$ bodyweight (bw)/day) can be extrapolated (see also [14]). The US Flavor and Extract Manufacturers Association (FEMA) has estimated the possible average daily intake as $35 \mathrm{mg}$ ( $0.47 \mathrm{mg} / \mathrm{kg}$ bw/day) [53] while Morris et al. [54] estimated a range of $40-80 \mathrm{mg}(0.53-1.07 \mathrm{mg} / \mathrm{kg}$ bw/day), with worst case levels up to $200 \mathrm{mg}(2.67 \mathrm{mg} / \mathrm{kg}$ bw/day) [55].

From the acetaldehyde content found in our survey for each food group and the estimated intake of each group for a selected population, the acetaldehyde exposure can be estimated. Regarding the exposure to acetaldehyde on a population basis, the food intake assessed during the German National Nutrition Survey II [56] can be taken as basis. The exposure can be estimated by multiplying the daily consumption amount of each food group with the acetaldehyde content of this food group found in our survey. The results are shown in Table 2 for different exposure scenarios. We estimate that the major factors for acetaldehyde exposure are alcohol-free beverages, especially for men who have a higher consumption of this group than women. Women compensate this, however, by their higher consumption of milk products, fruits, and vegetables (Figure 8 ). The average exposure from food (without alcoholic beverages) would be around $40 \mu \mathrm{g} / \mathrm{kg}$ bw/day for the German population. 


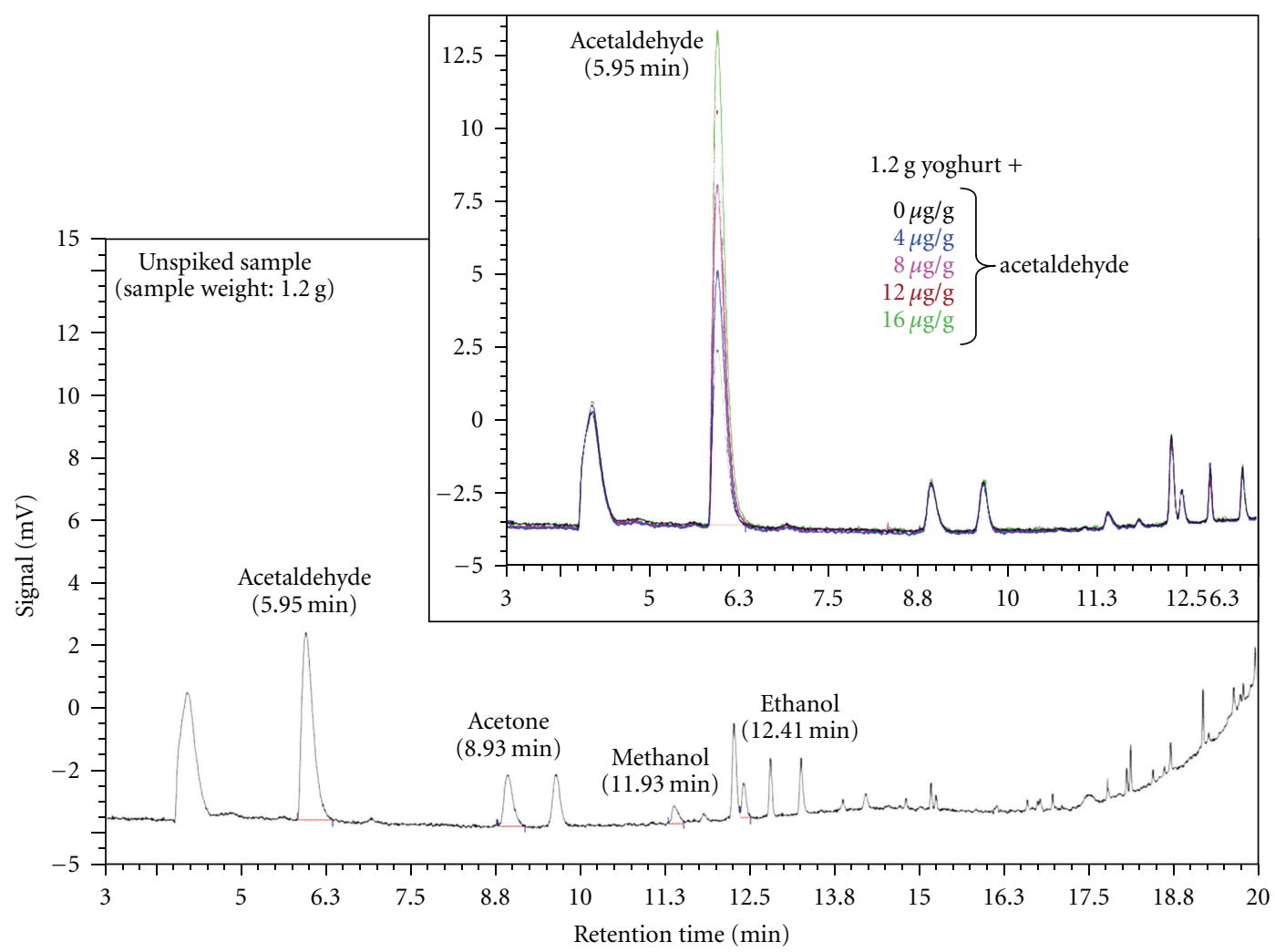

FIgURE 6: GC/FID chromatogram of a yoghurt sample ( $8.4 \mathrm{mg} / \mathrm{kg}$ acetaldehyde).

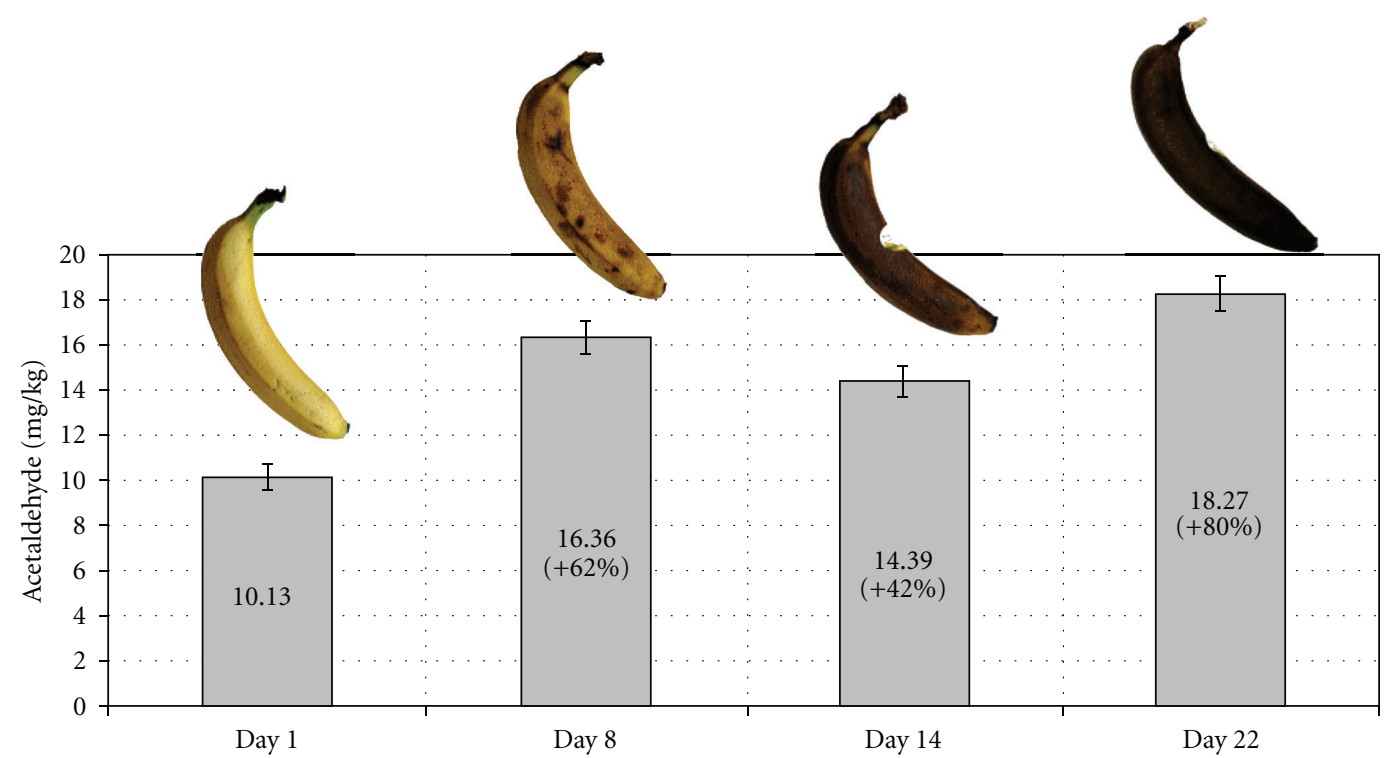

FIGURE 7: Changes in acetaldehyde content of bananas during ripening.

\section{Conclusions}

This exposure estimated in our study is considerably lower than the previous assumptions (e.g., from JECFA or FEMA), which were derived from very old occurrence data or industrial production amounts for the use as food flavour additive. This shows the need for further research on acetaldehyde in foods, as the exposure situation appears to be far from well characterized.

Nevertheless, the margin of exposure (MOE) calculated according to our previous studies $[10,11]$ for the exposure estimated in this study would be 1175 , which is in a similar region to the MOEs of other food carcinogens such as acrylamide, furan, aflatoxins, or nitrosamines [57-60]. Of 


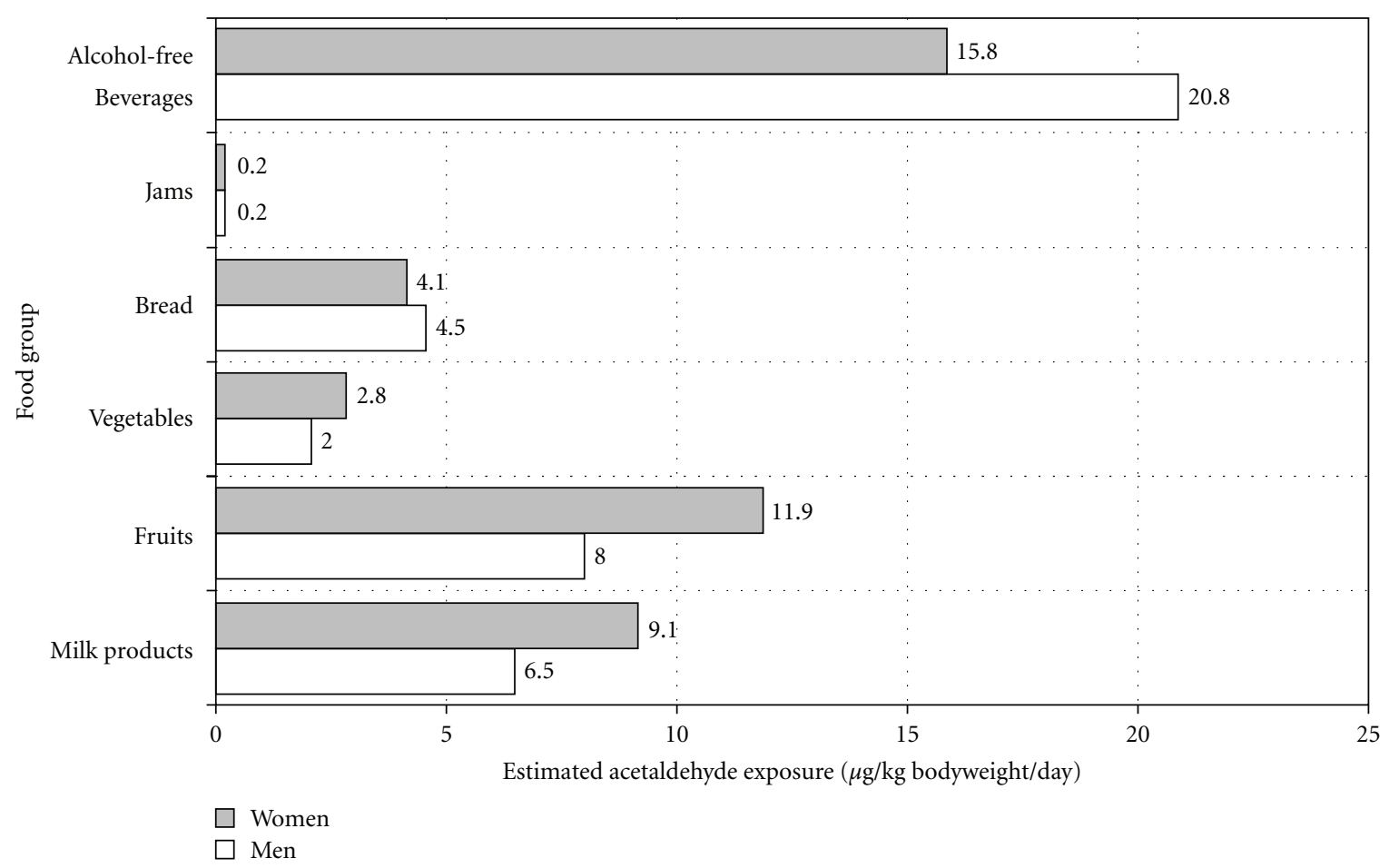

FIgURe 8: Acetaldehyde exposure estimation due to the food groups analyzed in this study.

course, this risk assessment must be treated as preliminary as we only have analyzed certain food groups; however, these were selected according to the risk of containing acetaldehyde. MOEs above 10000 are normally judged as of low relevance for health by the European Food Safety Authority (EFSA) [61], but our calculation for acetaldehyde is below this threshold. Furthermore, this assessment disregards genetic polymorphisms in subgroups of the population that could lead to an accumulation of acetaldehyde by reduced metabolic activity $[62,63]$.

We think that this preliminary risk assessment justifies further studies into acetaldehyde exposure from food, and risk managers should also consider the possibility to reduce the exposure by disallowing the practice of acetaldehyde addition as a flavour compound.

\section{Acknowledgment}

Iris Woock is thanked for preparing the microscopic photographs.

\section{References}

[1] M. Soffritti, F. Belpoggi, L. Lambertini, M. Lauriola, M. Padovani, and C. Maltoni, "Results of long-term experimental studies on the carcinogenicity of formaldehyde and acetaldehyde in rats," Annals of the New York Academy of Sciences, vol. 982, pp. 87-105, 2002.

[2] R. A. Woutersen, L. M. Appelman, A. Van Garderen-Hoetmer, and V. J. Feron, "Inhalation toxicity of acetaldehyde in rats. III. carcinogenicity study," Toxicology, vol. 41, no. 2, pp. 213-231, 1986.
[3] IARC working group on the evaluation of carcinogenic risks to humans, "Acetaldehyde," IARC Monographs on the Evaluation of Carcinogenic Risks to Humans, vol. 71, pp. 319-335, 1999.

[4] B. Secretan, K. Straif, R. Baan et al., "A review of human carcinogens_-part e: tobacco, areca nut, alcohol, coal smoke, and salted fish," Lancet Oncology, vol. 10, no. 11, pp. 10331034, 2009.

[5] J. A. Theruvathu, P. Jaruga, R. G. Nath, M. Dizdaroglu, and P. J. Brooks, "Polyamines stimulate the formation of mutagenic 1,N2/-propanodeoxyguanosine adducts from acetaldehyde," Nucleic Acids Research, vol. 33, no. 11, pp. 3513-3520, 2005.

[6] P. J. Brooks and J. A. Theruvathu, "DNA adducts from acetaldehyde: implications for alcohol-related carcinogenesis," Alcohol, vol. 35, no. 3, pp. 187-193, 2005.

[7] H. K. Seitz and F. Stickel, "Molecular mechanisms of alcoholmediated carcinogenesis," Nature Reviews Cancer, vol. 7, no. 8, pp. 599-612, 2007.

[8] S. Stein, Y. Lao, I. Y. Yang, S. S. Hecht, and M. Moriya, "Genotoxicity of acetaldehyde- and crotonaldehyde-induced $1, N^{2}$ propanodeoxyguanosine DNA adducts in human cells," Mutation Research, vol. 608, no. 1, pp. 1-7, 2006.

[9] IARC Working Group on the Evaluation of Carcinogenic Risks to Humans, "Alcohol consumption and ethyl carbamate," IARC Monographs on the Evaluation of Carcinogenic Risks to Humans, vol. 96, pp. 1-1428, 2010.

[10] F. Kanteres, D. W. Lachenmeier, and J. Rehm, "The contribution of acetaldehyde from alcohol to cancer: a review and exposure estimate for Germany," Sucht, vol. 55, no. 2, pp. 111$117,2009$.

[11] D. W. Lachenmeier, F. Kanteres, and J. Rehm, "Carcinogenicity of acetaldehyde in alcoholic beverages: risk assessment outside ethanol metabolism," Addiction, vol. 104, no. 4, pp. 533-550, 2009. 
[12] D. W. Lachenmeier, "Carcinogens in food: opportunities and challenges for regulatory toxicology," Open Toxicology Journal, vol. 3, pp. 30-34, 2009.

[13] D. W. Lachenmeier and Y. B. Monakhova, "Short-term salivary acetaldehyde increase due to direct exposure to alcoholic beverages as an additional cancer risk factor beyond ethanol metabolism," Journal of Experimental \& Clinical Cancer Research, vol. 30, no. 1, Article ID 3, 2011.

[14] D. W. Lachenmeier, M. Uebelacker, K. Hensel, and J. Rehm, "Acetaldehyde in human diet: an underestimated risk factor for cancer," Deutsche Lebensmittel-Rundschau, vol. 106, no. 1, pp. 30-35, 2010.

[15] M. Salaspuro, "Acetaldehyde: a cumulative carcinogen in humans," Addiction, vol. 104, no. 4, pp. 551-553, 2009.

[16] V. J. Feron, H. P. Til, F. de Vrijer, R. A. Woutersen, F. R. Cassee, and P. J. Van Bladeren, "Aldehydes: occurrence, carcinogenic potential, mechanism of action and risk assessment," Mutation Research, vol. 259, no. 3-4, pp. 363-385, 1991.

[17] NTP, Profile of Acetaldehyde. 11th Report on Carcinogens (RoC), National Toxicology Program, Research Triangle Park, NC, USA, 2005.

[18] L. M. Nijssen, C. A. van Ingen-Visscher, and J. J. H. Donders, VCF (Volatile Compounds in Food) Database, TNO Quality of Life, Zeist, The Netherlands, 2009.

[19] European Commission, "Commission regulation (EC) no 2870/2000 laying down community reference methods for the analysis of spirits drinks," Official Journal of the European Communities, vol. L333, pp. 20-46, 2000.

[20] J. Kelly, S. Chapman, P. Brereton et al., "Gas chromatographic determination of volatile congeners in spirit drinks: interlaboratory study," Journal of Association of Analytical Communities International, vol. 82, no. 6, pp. 1375-1388, 1999.

[21] D. W. Lachenmeier, E.-M. Sohnius, R. Attig, and M. G. López, "Quantification of selected volatile constituents and anions in Mexican Agave spirits (Tequila, Mezcal, Sotol, Bacanora)," Journal of Agricultural and Food Chemistry, vol. 54, no. 11, pp. 3911-3915, 2006.

[22] D. W. Lachenmeier and E-M. Sohnius, "The role of acetaldehyde outside ethanol metabolism in the carcinogenicity of alcoholic beverages: evidence from a large chemical survey," Food and Chemical Toxicology, vol. 46, no. 8, pp. 2903-2911, 2008.

[23] D. W. Lachenmeier, B. Sarsh, and J. Rehm, "The composition of alcohol products from markets in Lithuania and Hungary, and potential health consequences: a pilot study," Alcohol and Alcoholism, vol. 44, no. 1, pp. 93-102, 2009.

[24] D. W. Lachenmeier, P. T. H. Anh, S. Popova, and J. Rehm, “The quality of alcohol products in Vetnam and its implications for public health," International Journal of Environmental Research and Public Health, vol. 6, no. 8, pp. 2090-2101, 2009.

[25] D. W. Lachenmeier, A. V. Samokhvalov, J. Leitz et al., "The composition of unrecorded alcohol from Eastern Ukraine: is there a toxicological concern beyond ethanol alone?" Food and Chemical Toxicology, vol. 48, no. 10, pp. 2842-2847, 2010.

[26] F. Kanteres, J. Rehm, and D. W. Lachenmeier, "Artisanal alcohol production in Mayan Guatemala: chemical safety evaluation with special regard to acetaldehyde contaminaton," Science of the Total Environment, vol. 407, no. 22, pp. 5861$5868,2009$.

[27] I. Papaefstathiou, U. Bilitewski, and M. D. Luque de Castro, "Determination of acetaldehyde in liquid, solid and semi-solid food after pervaporation-derivatization," Fresenius Journal of Analytical Chemistry, vol. 357, no. 8, pp. 1168-1173, 1997.
[28] A. Ott, J. E. Germond, M. Baumgartner, and A. Chaintreau, "Aroma comparisons of traditional and mild yogurts: headspace gas chromatography quantification of volatiles and origin of $\alpha$-diketones," Journal of Agricultural and Food Chemistry, vol. 47, no. 6, pp. 2379-2385, 1999.

[29] H. G. Wager, "The determination of ethanol and acetaldehyde in plant tissue by low-temperature diffusion," The Analyst, vol. 83, no. 986, pp. 291-295, 1958.

[30] A. Ott, L. B. Fay, and A. Chaintreau, "Determination and origin of the aroma impact compounds of yogurt flavor," Journal of Agricultural and Food Chemistry, vol. 45, no. 3, pp. 850-858, 1997.

[31] C. J. P. Eriksson, Y. Mizoi, and T. Fukunaga, "The determination of acetaldehyde in human blood by the perchloric acid precipitation method: the characterization and elimination of artefactual acetaldehyde formation," Analytical Biochemistry, vol. 125, no. 2, pp. 259-263, 1982.

[32] International Programme on Chemical Safety, Acetaldehyde, World Health Organization, Geneva, Switzerland, 1995.

[33] T. Miyake and T. Shibamoto, "Quantitative analysis of acetaldehyde in foods and beverages," Journal of Agricultural and Food Chemistry, vol. 41, no. 11, pp. 1968-1970, 1993.

[34] D. W. Lachenmeier, S. Gumbel-Mako, E. M. Sohnius, A. KeckWilhelm, E. Kratz, and G. Mildau, "Salivary acetaldehyde increase due to alcohol-containing mouthwash use: a risk factor for oral cancer," International Journal of Cancer, vol. 125, no. 3, pp. 730-735, 2009.

[35] K. Schulz, J. Dreßler, E. M. Sohnius, and D. W. Lachenmeier, "Determination of volatile constituents in spirits using headspace trap technology," Journal of Chromatography A, vol. 1145, no. 1-2, pp. 204-209, 2007.

[36] United States Pharmacopoeia, United States Pharmacopeial Convention, United States Pharmacopoeia, Rockville, Md, USA, 2008.

[37] M. Roth, S. Hartmann, R. Renner, and W. Hörtig, "Sampling on a risk basis in the context of official control in the German federal state Baden-Württemberg," Deutsche LebensmittelRundschau, vol. 103, no. 2, pp. 45-52, 2007.

[38] DIN 32 645, Chemische Analytik: Nachweis-, Erfassungs- und Bestimmungsgrenze, Ermittlung unter Wiederholbedingungen. Begriffe, Verfahren, Auswertung, Beuth, Berlin, Germany, 2008.

[39] DIN 32 633, Chemische Analytik: Verfahren der Standardaddition. Verfahren, Auswertung, Beuth, Berlin, Germany, 1998.

[40] J. Linssen, H. Reitsma, and J. Cozijnsen, "Static headspace gaschromatography of acetaldehyde in aqueous foods and polythene terephthalate," Zeitschrift für Lebensmittel-Untersuchung und-Forschung, vol. 201, no. 3, pp. 253-255, 1995.

[41] A. Rizzolo, F. Gerli, C. Prinzivalli, S. Buratti, and D. Torreggiani, "Headspace volatile compounds during osmotic dehydration of strawberries (cv camarosa): influence of osmotic solution composition and processing time," LWT Food Science and Technology, vol. 40, no. 3, pp. 529-535, 2007.

[42] I. Sodini, P. Morin, A. Olabi, and R. Jiménez-Flores, "Compositional and functional properties of buttermilk: a comparison between sweet, sour, and whey buttermilk," Journal of Dairy Science, vol. 89, no. 2, pp. 525-536, 2006.

[43] P. Morin, R. Jiménez-Flores, and Y. Pouliot, "Effect of processing on the composition and microstructure of buttermilk and its milk fat globule membranes," International Dairy Journal, vol. 17, no. 10, pp. 1179-1187, 2007.

[44] D. Beshkova, E. Simova, G. Frengova, and Z. Simov, "Production of flavour compounds by yogurt starter cultures," Journal of Industrial Microbiology \& Biotechnology, vol. 20, no. 3-4, pp. 180-186, 1998. 
[45] A. Buettner and P. Schieberle, "Application of a comparative aroma extract dilution analysis to monitor changes in orange juice aroma compounds during processing," ACS Symposium Series, vol. 782, pp. 33-45, 2001.

[46] E. D. Lund, C. L. Kirkland, and P. E. Shaw, "Methanol, ethanol, and acetaldehyde contents of citrus products," Journal of Agricultural and Food Chemistry, vol. 29, no. 2, pp. 361-366, 1981.

[47] A. Buettner and P. Schieberle, "Evaluation of aroma differences between hand-squeezed juices from Valencia late and navel oranges by quantitation of key odorants and flavor reconstitution experiments," Journal of Agricultural and Food Chemistry, vol. 49, no. 5, pp. 2387-2394, 2001.

[48] A. Buettner and P. Schieberle, "Evaluation of key aroma compounds in hand-squeezed grapefruit juice (citrus paradisi macfayden) by quantitation and flavor reconstitution experiments," Journal of Agricultural and Food Chemistry, vol. 49, no. 3, pp. 1358-1363, 2001.

[49] J. Shipton, F. B. Whitfield, and J. H. Last, "Extraction of volatile compounds from green peas (pisum sativum)," Journal of Agricultural and Food Chemistry, vol. 17, no. 5, pp. 1113-1118, 1969.

[50] D. D. Jones and R. M. Greenshield, "Volatile constituents of vinegar. I. A survey of some commercially available malt vinegars," Journal of the Institute of Brewing, vol. 75, no. 5, pp. 457-463, 1969.

[51] JECFA, Safety Evaluation of Certain Food Additives and Contaminants, vol. 40 of WHO Food Additives Series, World Health Organization, Geneva, Switzerland, 1998.

[52] FSC, Evaluation of Food Additives: Acetaldehyde, Japan Food Safety Commission, Tokyo, Japan, 2005.

[53] G. A. Burdock, Fenaroli's Handbook of Flavour Ingredients, CRC Press, Boca Raton, Fla, USA, 2004.

[54] J. B. Morris, D. E. Robinson, T. A. Vollmuth, R. P. Brown, and B. E. Domeyersect, "A parallelogram approach for safety evaluation of ingested acetaldehyde," Regulatory Toxicology and Pharmacology, vol. 24, no. 3, pp. 251-263, 1996.

[55] C. J. P. Eriksson, "Measurement of acetaldehyde: what levels occur naturally and in response to alcohol?" Novartis Foundation Symposium, vol. 285, pp. 247-255, 2007.

[56] Nationale Verzehrsstudie, vol. 2, Max-Rubner-Institut, Karlsruhe, Germany, 2008.

[57] L. S. Gold, B. N. Ames, and T. H. Slone, How Many Fold Lower Is Human Exposure Than the Dose That Gave Rodents Cancer: Margin of Exposure, MOE (Rodent Cancer Dose/Human Exposure). Carcinogenic Potency Project, University of California, Berkeley, Calif, USA, 2008, http://potency.berkeley.edu/ MOEtable.html.

[58] J. O’Brien, A. G. Renwick, A. Constable et al., "Approaches to the risk assessment of genotoxic carcinogens in food: a critical appraisal," Food and Chemical Toxicology, vol. 44, no. 10, pp. 1613-1635, 2006.

[59] D. W. Lachenmeier, H. Reusch, and T. Kuballa, "Risk assessment of furan in commercially jarred baby foods, including insights into its occurrence and formation in freshly homecooked foods for infants and young children," Food Additives and Contaminants, vol. 26, no. 6, pp. 776-785, 2009.

[60] D. Benford, P. M. Bolger, P. Carthew et al., "Application of the margin of exposure (MOE) approach to substances in food that are genotoxic and carcinogenic," Food and Chemical Toxicology, vol. 48, no. 1, pp. S2-S24, 2010.

[61] EFSA, "Opinion of the scientific committee on a request from EFSA related to a harmonised approach for risk assessment of substances which are both genotoxic and carcinogenic,"
European Food Safety Authority Journal, vol. 282, pp. 1-31, 2005.

[62] A. Yokoyama, E. Tsutsumi, H. Imazeki, Y. Suwa, C. Nakamura, and T. Yokoyama, "Polymorphisms of alcohol dehydrogenase$1 \mathrm{~b}$ and aldehyde dehydrogenase- 2 and the blood and salivary ethanol and acetaldehyde concentrations of Japanese alcoholic men," Alcoholism, vol. 34, no. 7, pp. 1246-1256, 2010.

[63] M. Salaspuro, "Acetaldehyde as a common denominator and cumulative carcinogen in digestive tract cancers," Scandinavian Journal of Gastroenterology, vol. 44, no. 8, pp. 912-925, 2009. 


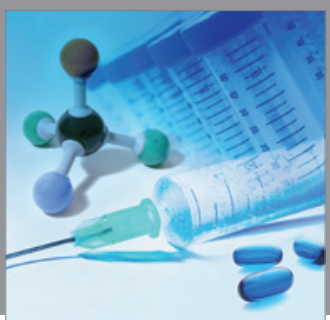

International Journal of

Medicinal Chemistry

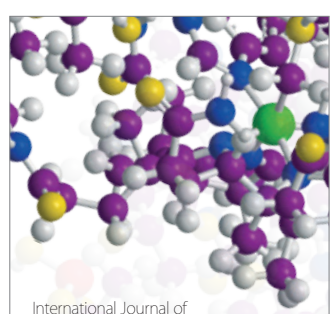

Carbohydrate Chemistry

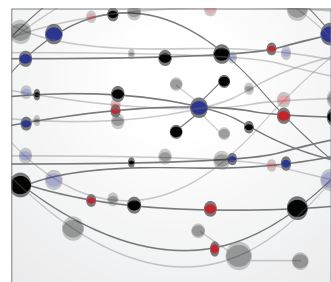

The Scientific World Journal
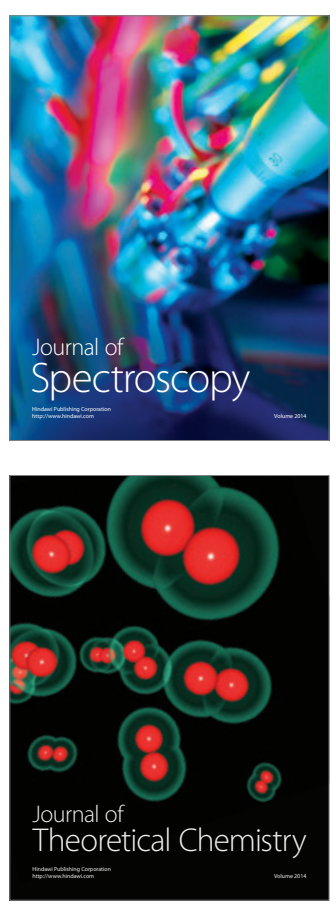
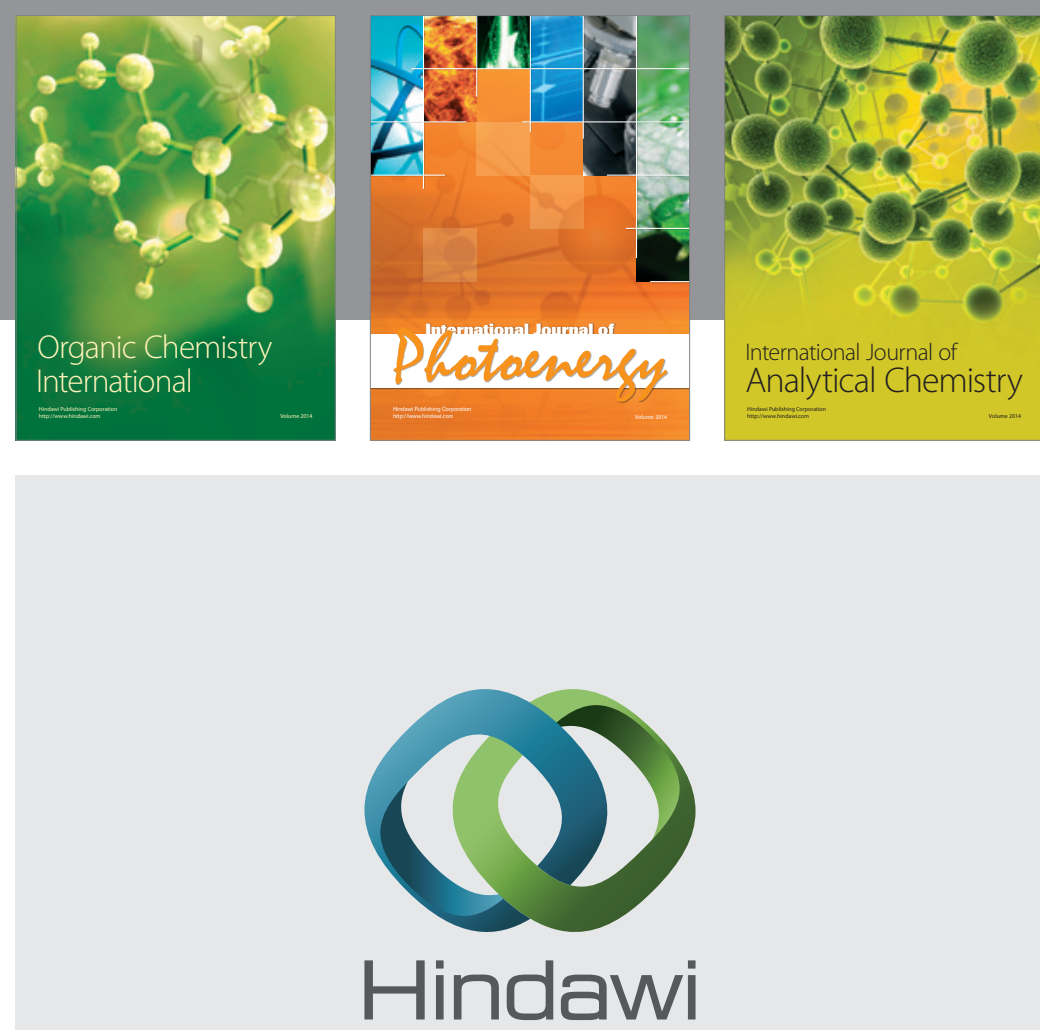

Submit your manuscripts at

http://www.hindawi.com
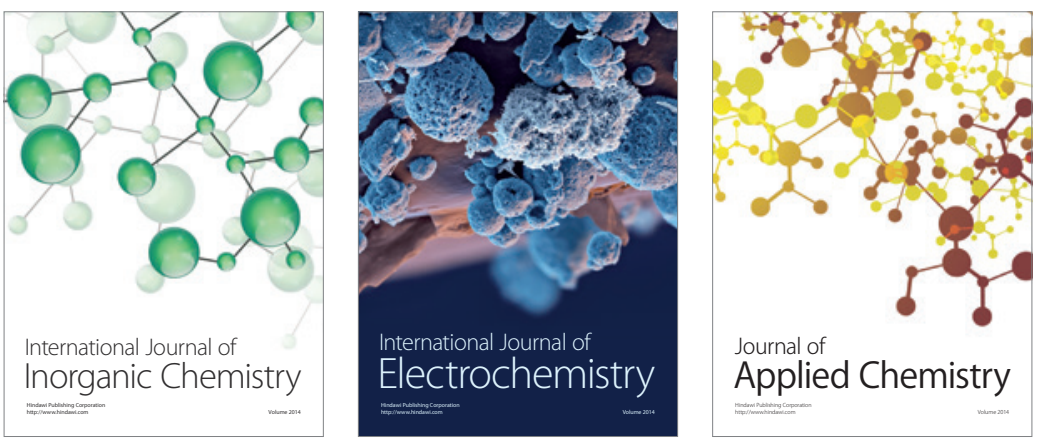

Journal of

Applied Chemistry
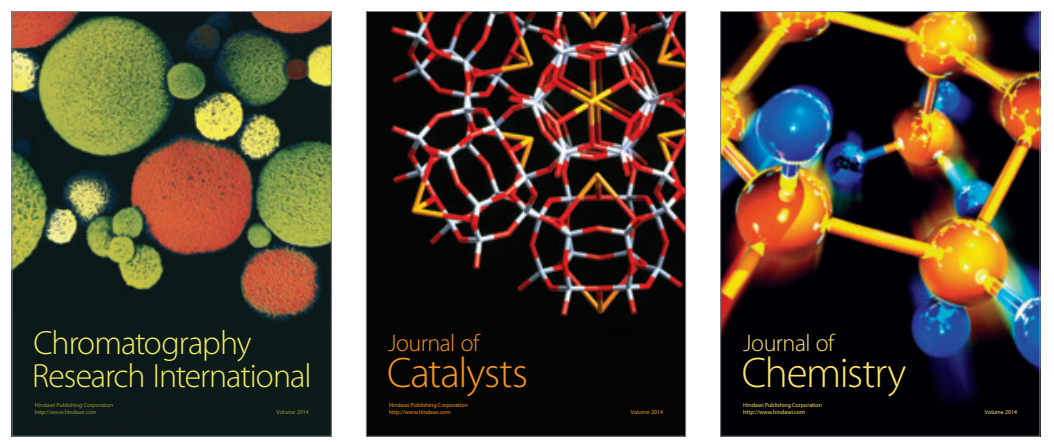
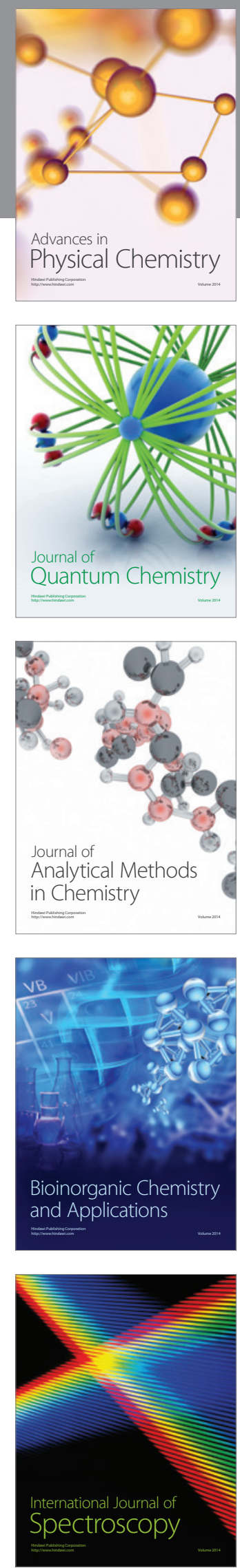